\title{
The Nobel Prize as a Reward Mechanism in the Genomics Era: Anonymous Researchers, Visible Managers and the Ethics of Excellence
}

\author{
Hub Zwart
}

Received: 29 March 2009 / Accepted: 26 May 2010 / Published online: 9 July 2010

(C) The Author(s) 2010. This article is published with open access at Springerlink.com

\begin{abstract}
The Human Genome Project (HGP) is regarded by many as one of the major scientific achievements in recent science history, a large-scale endeavour that is changing the way in which biomedical research is done and expected, moreover, to yield considerable benefit for society. Thus, since the completion of the human genome sequencing effort, a debate has emerged over the question whether this effort merits to be awarded a Nobel Prize and if so, who should be the one(s) to receive it, as (according to current procedures) no more than three individuals can be selected. In this article, the HGP is taken as a case study to consider the ethical question to what extent it is still possible, in an era of big science, of large-scale consortia and global team work, to acknowledge and reward individual contributions to important breakthroughs in biomedical fields. Is it still viable to single out individuals for their decisive contributions in order to reward them in a fair and convincing way? Whereas the concept of
\end{abstract}

This article is part of the research programme of the Centre for Society and Genomics, funded by NGI, and was first presented in outline at the Common Knowledge Expert Seminar, Nijmegen, the Netherlands, May 29, 2008.

H. Zwart ( $\bowtie)$

Faculty of Science, Radboud University Nijmegen,

Department of Philosophy \& Science Studies,

Centre for Society \& Genomics Institute for Science,

Innovation \& Society,

P.O. Box 9010, 6500 GL Nijmegen, The Netherlands

e-mail: h.zwart@science.ru.nl the Nobel prize as such seems to reflect an archetypical view of scientists as solitary researchers who, at a certain point in their careers, make their one decisive discovery, this vision has proven to be problematic from the very outset. Already during the first decade of the Nobel era, Ivan Pavlov was denied the Prize several times before finally receiving it, on the basis of the argument that he had been active as a research manager (a designer and supervisor of research projects) rather than as a researcher himself. The question then is whether, in the case of the HGP, a research effort that involved the contributions of hundreds or even thousands of researchers worldwide, it is still possible to "individualise" the Prize? The "HGP Nobel Prize problem" is regarded as an exemplary issue in current research ethics, highlighting a number of quandaries and trends involved in contemporary life science research practices more broadly.

Keywords Human Genome Project · Nobel Prize · Research ethics $\cdot$ Fairness of reward mechanism in biomedical research

...the capital, invested in safe securities by my executors, shall constitute a fund, the interest on which shall be annually distributed in the form of prizes to those who, during the preceding year, shall have conferred the greatest benefit on mankind... (excerpt from Alfred Nobel's will).

We all try, but some succeed (Humphrey Bogart in Casablanca). 
Qu'importe qui parle? En cette indifférence s'affirme le principe éthique, de plus foundamental peut-être, de l'écriture contemporaine (Michel Foucault 1994, 789)

\section{Introduction: The Century of the Nobel Prize}

The first Nobel Prize in Physiology or Medicine, like those in Chemistry, Physics, Literature and Peace, was awarded in 1901. Indeed, the twentieth century can be regarded as the century of the Nobel Prize. From the very outset, however, Nobel Prizes in general, and the one in Physiology or Medicine in particular, have been plagued by what can be referred to as a basic tension between reality and ideal. By singling out individual scientists as paragons of scientific achievement in their fields, the Nobel Prize seems to endorse the "archetypical" idea of a solitary researcher making his or her one great discovery or invention, to the benefit of mankind, as it is stated in Alfred Nobel's will. Although from the 1950s onwards Nobel Prizes in Physiology or Medicine have usually been awarded to three persons rather than one, as had been the common rule during the first half of the century, these three persons are still usually seen as individual scientific "heavy weights" working in a more or less independent and "researcher-driven" fashion, rather than as "science workers" firmly embedded in extended research networks or consortia. Whereas solitude, perseverance, creativity and flashing insights are bound to remain basic ingredients of scientific discovery, the archetypical idea of the scientific hero seems nonetheless increasingly at odds with the way in which research is actually conducted. And although (as will be pointed out below) this basic tension is as old as the Nobel Prize in Physiology or Medicine itself, it has become increasingly problematic as the research practices involved continue to expand in terms of pace, complexity and scale.

This intricate issue can be addressed from various angles: history of science, sociology of science, science ethics, etc. In this contribution, I intend to address it from a normative perspective, as a quandary of contemporary science ethics, thereby regarding the awarding of Nobel Prizes first and foremost as a moral issue. The Nobel Prize is considered by many as the acme of acknowledgement, and, as Merton and others have pointed out, acknowledgement (in various formats, ranging from citations, chairs and appointments up to international prizes) is crucially important in science. But as such, it is also likely to be highly controversial, raising a host of normative issues and deliberations in terms of transparency and fairness, both on a general level and with respect to specific cases. Moreover, by being awarded a Nobel Prize, the researchers involved are singled out as models or examples for others, as exemplary scientists setting a standard, not only in terms of the discoveries or inventions they actually made, but also in terms of crucial scientific values they came to embody such as disinterestedness, reliability, honesty, meticulousness and the like. Or, to formulate it in a negative vein: should a Nobel Prize winner be exposed as a dishonest person and a fraud, science as such would be in danger of seeing its credibility diminished. Awarding the Prize on the basis of a particular achievement, a groundbreaking experiment or publication, conveys the message that this is how science ought to be done. And this explains why the Nobel Prize in Physiology or Medicine has stirred such a plethora of normative controversies and why the actual decisions made seem to become increasingly contested over the years: the awarding of such Prizes involves more than counting citations or determining an author's H-factor. It entails a normative statement concerning the value and values involved in a highly dynamical and rapidly evolving phenomenon called science. The type of considerations for selecting and evaluating candidates are bound to change as science develops over time. As "Nobel Prize historian" Robert Friedman phrases it, "success or failure in winning [the prize] has not depended upon timeless, fixed standards of excellence. Rather, the changing priorities and agendas of committee members, as well as their comprehension of scientific accomplishment, have been critical" (2001, ix).

Yet, although my paper will basically take a science ethics perspective, sociological and historical analyses are crucially important when it comes to providing the "input" for a normative assessment. Ethical considerations have to build and critically reflect on empirical analyses of how practices of knowledge production are actually evolving and how controversies and dilemmas concerning the Nobel Prize in Physiology or Medicine have actually been 
dealt with. Moreover, rather than addressing this issue on a general level, I will focus on a particular case study, namely the Human Genome Project (HGP). Should the sequencing of the human genome be awarded by the Nobel Prize and, if so, who should be the (one, two or three) persons to receive it? By focussing on this case study I intend to address in a concrete manner the more general question: to what extent can the Nobel Prize in Physiology or Medicine still be regarded as a fair and convincing mechanism of reward in an era of anonymity, global networks, multiple authorship, private-public partnerships and Big Science.

\section{The Human Genome Project}

The HGP will certainly present an interesting but also a difficult case for Nobel Prize committees to deal with. The sequencing of the human genome is regarded by many as one of the major scientific highlights in recent science history. And it may be seen as highly symbolic perhaps that the human genome sequence was published in 2001, exactly 100 years after the first Nobel Prizes were awarded (International Human Genome Sequencing Consortium [IHGSC] 2001). Moreover, from the very outset, the HGP has generated a plethora of claims concerning the benefits for humankind that are expected to result from it in terms of health, sustainability and empowerment. Thus, from the very start, this project, the final conclusion as it were of a long journey that began with the re-discovery of Mendel in 1900 and the disclosure of the structure by DNA by Watson and Crick in 1953 (Watson and Crick 1953), has raised the question whether a Nobel prize should be attached to it - not a regular one, moreover, but rather a kind of mega-Nobel prize, the Nobel prize of Nobel Prizes, and perhaps even more than just one. Indeed, a decade of Nobel Prizes might be expected to flow from it. The history of the HGP is more or less haunted by this question and the likelihood that some of its key protagonists would one day receive a phone call from Stockholm has been an issue of speculation and dispute on various occasions. Indeed, protagonists such as Craig Venter consciously tailored their publication policies so as to increase the likelihood of one day earning the biggest prize in science (Shreeve 2004). Moreover, the HGP is regarded as the "flagship project" of genomics as an emerging technoscientific field, an endeavour claimed to have irreversibly and fundamentally changed the way in which research in the life sciences is done (Collins et al. 2003). Another important reason for focussing the discussion on the HGP is that more than any other recent achievement in science, it exemplifies the current transformations that are taking place in the way in which scientific knowledge is produced. The question basically is what these transformations - this "scientific revolution" that is clearly connected with the emergence of Big Science - imply (from a normative perspective) for the scientific individual. The idea of a Nobel Prize presupposes that a major scientific feat can still be meaningfully attributed to the talents and commitment of one, two or three concrete individuals at most. The era of Big Science, as exemplified by the HGP, raises the question to what extent this presupposition is still feasible.

\section{Big Science}

The Big Science concept builds on the scientometric observation, put forward by De Solla Price (1963) and others, that there is a tendency in modern research towards exponential growth, regardless of whether this refers to the number of researchers, author names, publications, journals, journal articles, citations or any other quantitative indicator. As all these indicators display the tendency to double at regular intervals, scientific inquiry has by now evolved into a rather massive phenomenon, and the archetypical image of the solitary researcher increasingly seems to become marginalised as a relic from the past. Moreover, the Big Science concept not only refers to the actual number of researchers working and collaborating within a particular field, but also to the increased dependence of current research on massive, expensive and sophisticated technologies, as exemplified by the particle collider at CERN, but also by the automated sequencing machines of genomics research, involving large-scale investments and sophisticated management structures. Publications in particle physics in which CERN findings are reported may have several hundred authors, and biology is now moving in the same direction with the advent of the industrial-scale work required for sequencing genomes (Bishop 2003). As the number of individuals responsible for single breakthroughs in scientific research has 
gradually increased, so too has the sentiment that a limit of three recipients for each prize may be too restrictive. Whereas most discoveries in modern science arise from the efforts of multiple individuals, no more than three individuals can receive the prize in each category. In fact, the current limit of three for each prize is itself a compromise, representing a revision of Nobel's original bequest, which speaks of only one recipient per prize. Might the Nobel Foundation now be tempted to make the awards even more inclusive? The Nobel Foundation does not seem inclined to move in this direction (Bishop 2003, 24).

In what manner does the emergence of Big Science undermine the credibility of policies of individual recognition as such? In this paper I will argue that, as we experience a period of increase in scale and pace, of globalisation of scientific effort, individual researchers increasingly tend to operate in the context of massive knowledge networks. They have become anonymous rather than autonomous. Yet, this does not mean that the ethical dimension of individual commitment is being erased altogether, quite the contrary. Rather, I see it as a challenge for contemporary science ethics to address the novel ethical problems and dilemmas arising in such complex, competitive and large-scale research environments in a convincing way (Zwart 2008a). This implies that, besides traditional values such as autonomy and perseverance in the face of adverse external pressures, academic excellence must increasingly involve other virtues and values as well, such as transparency, fairness and a communicative attitude towards the outside world. And the Nobel Prize, as a highly visible mechanism of acknowledgement in science, should reflect and acknowledge this. But before turning to the present, allow me to briefly browse through the Nobel Prize archives to see how this dilemma has been dealt with in the past.

\section{A Century of Nobel Prizes: From Ivan Pavlov to the HGP}

The responsibility for awarding the Nobel Prize in Physiology or Medicine lies with the Karolinska Institute in Stockholm, but the details of nomination, evaluation and selection are a well preserved secret (Feldman 2000). The statutes of the Nobel Foundation provide for strict secrecy and minutes from Committee meetings are non-existent, but we may still get to know something every now and then (http://nobelprize.org; Friedman 2001). Letters of correspondence and all letters of nomination since 1901 are kept in the committee's archive, while reports from the committee's advisers have been printed in separate internal volumes for each decade. After 50 years the Director of the Norwegian Nobel Institute may give access to these archival sources, primarily for the purpose of historical research. In 1976, for instance, the Nobel Foundation opened its archives to researchers up to the year 1950 (Friedman 2001).

These intriguing files and sources indicate that the tension outlined above has been haunting Nobel Prize procedures from the very start, as exemplified by the case of the Russian physiologist Ivan Pavlov. In four successive years $(1901,1902,1903,1904)$ Pavlov was nominated for the Nobel Prize in Physiology or Medicine, and each time the award committee confronted the same question: to what extent were the products of Pavlov's laboratory truly Pavlov's? The nominee had himself pronounced that his most substantial work, Lectures on the Work of the Main Digestive Glands (1897), was the achievement of his entire laboratory. He had credited his co-workers for conducting the experiments on which it was based. Furthermore, he referred readers seeking evidence for his arguments to their publications. Did Pavlov's major work, on which his nomination was based, represent his own original contributions to science, or was it merely a "compilation of the experimental dissertations?" (Todes 2002, xiii). Apparently endorsing the archetypical image of the scientist as a heroic lone investigator, the Nobel Prize Committee was now confronted with a more or less novel and apparently somewhat aberrant form of scientific knowledge production. Pavlov was actually a research manager rather than a solitary researcher, and his laboratory was a "factory," producing series of knowledge claims in a systematic fashion, constituting something of a knowledge production line, rather than a small-scale "workshop." Although Pavlov designed most of the trials and presented the research results in books, papers and lectures, the actual experiments were conducted by the "praktikanti" working in Pavlov's research facilities, hoping to complete their medical education in this manner. Nonetheless, in 1904, the prize finally was awarded 
to him. Still, the tension between the somewhat romantic image of the researcher as an individual, about to make his one key discovery, his highly personal contribution to the benefit of mankind, and the way in which scientific knowledge claims came to be produced by academic professionals in the course of the twentieth century, is bound to increase even further with the emergence of big science as exemplified by the HGP.

Indeed, one century later, in 2000 and 2001, a similar dilemma presented itself, but on an even grander scale. On June 26 2000, President Clinton, together with Francis Collins (Director of the International Human Genome Sequencing Consortium) and Craig Venter (his self-proclaimed rival, representing the privately owned Celera Company), announced at a press conference that the massive effort to sequence the human genome was reaching its completion. In 2001 , both teams published their results in a coordinated fashion, through milestone articles in Nature and Science respectively (IHGSC 2001, Venter et al. 2001). Collins' version listed 249 "authors", and Venter's publication 285 . These very numbers already indicate that Big Science as a phenomenon had reached the life sciences by now. As indicated above, CERN publications in the field of high energy physics already display such tendencies towards multiple authorship, but for the life sciences, where the bulk of academic research still tended to be conducted on the basis of individual research grants, this was something of a novelty. Both the press conference and the two key publications significantly fuelled the debate over the question whether this achievement should merit a Nobel Prize and, more complicated even, who should be the person or persons to receive it?

Shortly after the Nature publication, at a followup press conference in San Francisco organised during a meeting of the American Association for the Advancement of Science (AAAS) on February 18 2001, Francis Collins was explicitly asked whether the sequencing of the human genome warranted the Nobel Prize. In his (now famous) reply he stated that it would have to be given to 3,492 people to properly recognize everyone who had significantly contributed to this common effort (Davies 2002, 266). This attitude of humility and collectivism was already conveyed by the opening pages of the Nature publication itself, where Collins was listed simply as one author among many, allowing his colleague
Eric Lander (who in fact had done most of the actual writing) to be the first name on the list. In the case of Venter, things were slightly different. He put his own name first and at various occasions explicitly considered the likelihood that some of his highly cited key publications, notably the one on the human genome, might bring him the Nobel Prize some day. Both Collins and Venter, however, have subsequently published memoirs containing extensive reflections on their human genome years (Collins 2006, Venter 2007) and both documents make it abundantly clear how problematic it would be to give credit for the human genome sequencing effort to one, two or three individuals only. Although at crucial moments individual initiatives, personalities and eureka-like experiences of enlightenment remain undoubtedly important, life science research in the genomics era as such has irrevocably grown into a large-scale, collective endeavour.

If a Nobel Prize is to be awarded for deciphering the human genome, therefore, it is difficult to see how this can be done in a manner that is both meaningful and fair. As Robert Cook-Deegan phrases it: "the final truth is that no individual can take full credit" $(1995,71)$. Moreover, he argues that Nobel selection committees are "perpetually unfair" in conferring a prize on "winners" in science-ignoring the way science has changed so that most major advances require the efforts of hundreds of researchers, not one or two (ibid.). We seem to be faced with a real dilemma. On the one hand, when it comes to awarding the Nobel Prize somewhere in the near future, the human genome sequencing effort seems impossible to ignore. On the other hand it seems equally impossible to single out even a limited number of recipients in a convincing way. Each possible selection promises to be highly controversial. It appears to be an impossible task from the very outset.

What does this imply for the Nobel Prize as a reward mechanism in science? Since Merton we are familiar with the idea that scientists are much more interested in symbolic expressions of acknowledgement than in more mundane forms of reimbursement such as money. In order to "organize" acknowledgement, moreover, a number of mechanisms have been put in place such as citation indices, invited lectures, Nature covers and, at the very summit of the acknowledgement pyramid, the Nobel Prize. Yet, some of these acknowledgement mechanisms apparently stem from 
more or less outdated views on how science works. Nobel's bequest, spelled out in a single handwritten paragraph, seems to convey the idea of solitary researchers who, at a certain point during their long journey, have this one grand idea that will not only further science, but will also bring significant benefits to society. And indeed, discoveries of this type have existed and will no doubt continue to exist. The discovery of the structure of DNA by Watson and Crick may to a certain extent be seen in this manner, namely as a key discovery attributable to discrete individuals who embarked on a research effort of their own design. Although even in this case the role of codiscoverers incited much controversy, notably the question of whether the role of Rosalind Franklin had been duly acknowledged, the consensus gradually seems to have emerged that, although the work of Chargaff, Franklin and others had been pivotally important, Watson and Crick were nonetheless the ones who, at the crucial moment, choose the right track and made the final decisive steps (Maddox 2002). Yet, the overall picture seems to be that the tension between the basic image to which the Nobel Prize still tends to adhere and the actual practices of knowledge production as they currently evolve, continues to increase.

\section{Mechanisms of Acknowledgement}

This tension causes similar problems of course for other mechanisms of acknowledgement as well, such as citation indices (Wouters 1999, cf. Zwart 2005). Is the academic citation culture fair? Does it reflect the value of contributions in a meaningful way? Can a citation index be regarded as a reliable indicator when it comes to assessing the academic quality and impact of individuals or research groups? Robert Merton himself emphasized the lack of fairness in citation practices when he described what he referred to as the Matthew effect in science (Merton 1988, cf. Zwart 2005, 78). This concept builds on a famous saying borrowed from the Gospels: "For unto everyone that hath shall be given, and he shall have in abundance; but from him that hath not shall be taken away even what he hath" (Mt 13:12). In contemporary language: those of us who "have" are bound to receive even more, while the have-nots will become even more deprived. In terms of citation indices this means that most articles published by scientists will be cited only a few times, and then they will be forgotten completely, as if they had never been written. Indeed, most authors will be read and cited by only a limited number of readers, and eventually they will be ignored more or less for ever. Some articles, however, will be cited more often and the number of citations may even reach a certain critical limit. Beyond that point, the number of citations is bound to increase dramatically and exponentially. These publications will receive hundreds or even thousands of citations. Colleagues will continue to cite them for 20 or 30 years, until the paradigm to which the publication belongs expires. Thus, a limited number of authors may publish articles that really allow them to make their name, although the time and effort spent on writing them may not significantly exceed the amount of time and effort spent on publications that are treated less respectfully.

Various factors may contribute to the success rate of a particular paper. Eponymy is a well-known factor (Merton 1957/1973). If you want to become academically famous, invent a concept, a test, or identify a new disease to which your name may become attached. Although in the case of eponymy authorship is highly "functional"- simply a convenient way for referring to tests, concepts, illnesses or bodily partsit works. Hardly anyone who refers to the Stroop test or Stroop effect nowadays, will know anything about the individual bearing the surname Stroop. Hardly anyone will really have read his publication (Stroop 1935). Yet, his impact factor must be astounding.

\section{The Role of the Individual in Contemporary Science: From Autonomy to Anonymity and Beyond}

When it comes to defining the contribution made by individual scientists to progress in science, a series of trends can be identified. Initially, individuality was the focus of attention. Historians and other scholars studying science tended to see scientific progress as the achievement of a limited number of "heroes of science," a mere handful of "great men." An exemplification of this genre is the book Große Männer, published by Nobel Prize winner Wilhelm Ostwald in 1909. The author was an outstanding physical chemist who, later in life, became interested in the history of his field. In this book he describes and analyses the life stories of six prominent scientists 
of the nineteenth century, all of them male. Indeed, Ostwald explicitly states that, although examples of female researchers such as Madame Curie do exist, they are the exception to the rule - the rule being that, basically, scientific research is the work of a limited number of very great men.

Another interesting example is Paul de Kruif's bestseller The Microbe Hunters published in 1927 and devoted to scientific heroes such as Louis Pasteur and Robert Koch - the latter received the Nobel Prize in 1905, whereas the former died in 1895, six years before the Nobel Prizes began to be awarded. Paul de Kruif was "America's first great science writer" (Henig 2002). Born in 1890, he was trained as a bacteriologist. He published on streptococci and worked at the Rockefeller Institute until he was fired after publishing an anonymous, critical review of contemporary medical research. He was co-author, but not duly acknowledged as such, of Sinclair Lewis' novel Arrowsmith, published in 1925 , about a research institute clearly modelled after the Rockefeller Institute. Critics sometimes argue that in his narratives De Kruif relied too much on his imagination and enthusiasm for science, but two successful Hollywood movies and one successful Broadway play were based on Microbe Hunters, his most famous book. De Kruif's lively and readable account presents a rather supportive and protagonist-oriented portrayal of scientists as heroes, emphatically emphasizing the dramatic element inherent in experimental inquiry (Zwart 2004). Alfred Nobel's will, although extremely concise compared to the publications by Ostwald and De Kruif, seems to convey a similar view on progress in science: it is the epoch-making work of outstanding individuals who, because of one decisive feat that actually represents a life of tenacious effort, manage to contribute significantly and exceptionally to human knowledge and wellbeing.

From the 1970s and 1980s onwards, after the decline of existentialism so to speak, scepticism concerning the role of individual heroes quickly began to spread. Within the domain of science studies (broadly defined) there has been a conscious shift away from studying the work of individual scientists towards analysing networks, discourses and structures (Shortland and Yeo 1996). Science was no longer seen as the achievement of a limited number of "great men" (Lenard 1933). Rather, knowledge claims were now regarded as being produced by networks of more or less anonymous actors, so that any desire to focus on prominent individuals tended to be regarded with suspicion. This trend is exemplified by Bruno Latour's monograph entitled "The Pasteurisation of France" (1984/1988), which has been referred to as a Hamlet without Hamlet, since the hero whose name is referred to in the title is virtually absent in the book (Shortland and Yeo 1996). Science studies seemed to proclaim what Michel Foucault referred to as the "death" of the author-as-an-individual. According to Foucault, the history of scientific authorship displays a definite shift away from grand authoritative names (such as "Aristotle") as indices of genius and truth towards a purely functional form of authorship, where an author's name predominantly serves as, for instance, a search item in the context of information retrieval in PubMed and similar sources. And insofar authorship has become merely functional, various reward mechanisms, even Nobel Prizes, may perhaps be seen as predominantly functional as well, as techniques employed in the context of performance assessment of research groups or universities. Moreover, a Nobel Prize may come to play a "political" function as well. Awarding the Prize to someone like James Watson then means that the scientific establishment in place actually promotes a particular interpretation of what the biomedical life sciences are (namely that they should be regarded as more or less identical with molecular biology), at the expense of other possible interpretations. And indeed, Nobel laureates such as Watson are very powerful figures in science, deploying laureate status and other achievements to assume pivotal roles in processes of agenda-setting, Watson for instance in his role as the first director of the HGP (as Collins' predecessor).

Although it is important, of course, to be aware of the pitfalls of hero worship in science, and although the social and political dimensions of science (the structures, networks, institutions and power plays involved) are crucially important when it comes to understanding science as a real-life phenomenon, I believe that time has come to reconsider and reacknowledge the role played by the individual in scientific research. If we want to understand and assess the dynamics of scientific progress, attention should be paid to the micro-level, the level of individual activity as well (Zwart 2008b). After focussing on scientists as heroes (at the expense of social context), and after subsequently dismissing the individual 
dimension from science studies altogether (in favour of a more sociological, structural or science politics approach), I would like to argue that it is important to pay due attention again to the dimension of individuality as well, notably when it comes to addressing issues of normativity. To phrase it in a Foucauldian manner: science must be studied not on the level of science politics or epistemic communities only, but also on the level of the Self. The individual is the place where transformations of knowledge production become lively and concrete. How do individuals position themselves as responsible agents in the face of major transformations in knowledge production and technoscientific change?

In other words, what I advocate is not a reframing of science ethics in accordance with the archetypical image of the solitary researcher as a hero, whose heroism notably resides in his willingness to stubbornly oppose (rather than interactively endorse) the forces of collectivism. Quite the contrary, the emergence of Big Science has irrevocably reinforced the shift from "researcher-driven" research, conducted by autonomous, more or less free-floating individuals, to top-down programmatic efforts involving relatively large numbers of (more or less anonymous) science workers. This basic shift, from autonomy to anonymity, challenges and changes the meaning of research in general and of scientific authorship in particular, but does not erase the dimension of the individual Self altogether. To further elaborate this issue, I will build on a line of thinking that is often somewhat neglected in mainstream science ethics, namely the type of thinking about research and normativity exemplified by authors such as Nietzsche, Weber, Foucault and Sloterdijk. Nietzsche, for instance, whose talent for anticipation can hardly be questioned, already discerned that normal modern science is bound to entail the replacement of exceptional heroes by armies of anonymous individuals $(1980, \S 547)$. According to Nietzsche, however, a true scientist will endorse rather than deplore this anonymity as inevitable. For Nietzsche, a true scientist is not only someone who is willing to put his theories to the test, remaining susceptible to criticism, continuously on the alert not to deceive himself; for Nietzsche, the most important scientific virtue of all is self-denial. He sums this up in the simple phrase Was liegt an mir! It is not me that counts! For Nietzsche, this phrase articulates the core of the scientific ethos, the quintessence of being "in science" (1980, § 547). His view was taken up many years later by Michel Foucault who articulated his own version of the same idea: "Qu'importe qui parle?" For Foucault, the most fundamental ethical principle of contemporary scientific discourse resides in a basic indifference towards the issue of authorship (1994, 789; Cf. Zwart 2001). Science is, first and foremost, a discursive phenomenon in which author names serve as functional tools, notably in the context of information retrieval as we have seen. In normal science, academic authorship comes very close to anonymity, and there is a certain moral quality in the stoical acceptance of this fact. And indeed, it is in this vein that many Nobel laureates have written in retrospect about their Prize. J. Michael Bishop's How to win the Nobel Prize may serve as an example here, conveying a basic attitude of unobtrusiveness, for instance in the following sentences inserted right at the beginning of his account: "I felt less than fully deserving, because the discovery for which Harold [Varmus] and I were being honored was only in modest part of my own making..." etc. (Bishop 2003, 3).

Yet, this does not delete the dimension of individuality altogether-far from it. Rather, self-denial or unobtrusiveness are particular styles or modes for positioning oneself as a scientific individual. Following Nietzsche's lead in this, Foucault (1984, 1994), Sloterdijk (2010) and others have argued (as Nietzsche already did in more or less similar terms) that scientific research may be regarded as a kind of "practice of the Self", a form of moral self-edification for the individuals involved. Through training and intellectual asceticism, scientists gradually transform themselves, not only into highly reliable sources of information, but also into pioneers who, in the folds and margins of established discourse, are able to enter new terrains, to experiment with new techniques and thus to open up novel perspectives. Moreover, these authors emphasise that, although the conditions for scientific research and academic authorship have clearly changed, the axis of the Self continues to constitute a pivotal dimension of discourse production.

In other words, besides self-denial (i.e. the generous affirmation by scientists of their anonymity and fundamental dependence on others), there is another side to seeing scientific research as a "practice of the Self", namely the inherent strive towards selfimprovement, the basic will to challenge established conventions and the readiness to face new dawns. 
This means that in science, individual excellence is achieved by those who, through constant training and permanent re-education, remain eager and willing to acquire new vocabularies and skills. Those who see novel fields as test-beds and experimental settings, not only in the scientific sense, but also for exploring new dilemmas and trying out new ways of addressing normative issues. And this notably applies to science workers in the current era. Besides the willingness to learn to use new tools, such as ICT equipment or new computational techniques, it also implies the willingness to become adept in novel practices and fluent in novel professional vocabularies.

Important challenges facing scientific individuals in the Big Science era notably emerge in areas of management and communication. They must acquire the skills not only for governance of the Self, in order to establish themselves as a reliable and meticulous individual, as was already the case in the era of the lone scientific individual, but also for the governance of increasing numbers of academic others. Whereas traditionally science ethics tended to focus on the dilemmas of autonomous decision-making processes by researchers as individuals (micro-ethics), the new era of Big Science calls for an ethic that addresses social and political dimensions as well (macro-ethics). This involves important moral values such as responsibility, procedural fairness and transparency. Subsequently, one could argue that, in order to remain in line with these developments, the Nobel Prize will gradually have to evolve into a mechanism of acknowledgement for novel types of excellence, namely the excellence of scientists who, at a certain point in their career, successfully transform themselves from outstanding individual researchers into visible, accountable and communicative research managers. The question then remains whether those to whom this applies deserve to be singled out and credited, while the great majority of their devoted colleagues are bound to remain anonymous? Does the desire for individual acknowledgement still make sense?

\section{Desire for Acknowledgement}

In the movie Casablanca there is a famous and intriguing scene. At a certain point, a hero enters the room. Humphrey Bogart, albeit with a slightly cynical undertone in his voice, complements him with his achievements. The hero, assuming a quasi-humble posture, replies by saying that he simply tries to make a contribution, like so many other people do. Humphrey Bogart then retorts with one of his most famous one-liners: "We all try, but some succeed." Although many individuals are more or less committed, some individuals happen to make a contribution that is more decisive than those of others.

In various publications and seminars the French psychoanalyst Jacques Lacan argued that, rather than money, survival, sexual gratification or big automobiles, acknowledgement is what we are really after. Acknowledgement is our basic desire, fuelling creativity and perseverance, even under hazardous conditions, and science continues to rely on individuals who are willing to display this type of behaviour. Mechanisms of acknowledgement are important elements in what Lacan refers to as the "symbolic order." Symbolic rewards facilitate and consolidate professional collaboration. In psychoanalysis, the traditional Freudian idea had been that research is a kind of "sublimation." In the face of societal constraints, individuals at a certain point decide to invest their libido in activities other than sex and reproduction. For Freud, however, research remains a detour for individuals on their way to sexual intercourse and parenthood, their ultimate destination. Lacan has reframed this somewhat differently. A high citation index is an important gratification, a rewarding source of pleasure in itself. One of the pitfalls for scholars is what Lacan would refer to as "imaginary" recognition: acknowledgement by a limited number of close followers or friends nearby; the kind of recognition that typifies sectarism. That is why anonymity, globalisation and quantification are so important when it comes to defining performance indicators. It means that we are no longer dependent on the fragile benevolence (usually based on reciprocity rather than true merit) of those individuals who happen to constitute our immediate academic Umwelt. Thus, recognition is the symbolic bread we as researchers and scholars live by, and this implies that the Nobel Prize, rather than having become a ritual devoid of meaning or a relic from the past, still has to be taken quite seriously as an acme of symbolic acknowledgement.

Yet, building on what has been argued above, time has come to reconsider our basic mechanisms of acknowledgement in order to determine whether they 
still do justice to the way in which top scientists nowadays have to function. Every now and then it is important to update and, if necessary, adjust our ways of operationalizing and valuing excellence. Big Science has incited the emergence of new roles. Typical lab sites are not the only places where creativity becomes decisive and grand ideas flash up. This may also happen at airports and international conferences, or during board meetings and committee gatherings. The "big names" in contemporary life sciences, the pioneers and agenda-setters, the "first authors" of landmark publications, are often heavily involved in acquiring large-scale funding and in management of science. The role of the scientific research manager has become a pivotal one, not only in terms of making discoveries and discerning their importance, but also in assessing and addressing the complex ethical, political and strategic issues emerging in contemporary research. Besides a track record in laboratory research, scientists in positions of authority must develop new moral virtues besides the traditional ones connected with bench work, such as meticulousness, trustworthiness and selflessness. It is their challenge to become the visionaries of contemporary science: articulating "thick" views on what is happening in current research and what this may imply for our understanding of ourselves and nature, as well as for societies of the future; developing seismographic sensitivities towards important trends and promising developments. They are also the ones in a position to ensure that, as Alfred Nobel once stated it, expensive, large-scale research endeavours contribute sufficiently to the benefit of mankind. In short, science in the Big Science era has become an activity that is more complicated even than playing simultaneous chess. It might be compared to playing a variety of different games on different boards simultaneously, with each game having its own standards of excellence, its own morale. Is has become impossible to assess scientific performance (or excellence, as the current jargon calls it) on the basis of a single coherent set of criteria. This heterogeneity was already present in Nobel's will, where both academic excellence and societal relevance were regarded as important. Nobel Prize winners of the present and near future are bound to excel on an even broader spectrum. They will have to be virtuosi of heterogeneity, able to perform outstandingly in a broad range of complex and controversial settings.

\section{Does the HGP Merit a Nobel Prize?}

Let me now apply these considerations to the case study at hand, the HGP. It is a complicated "file" no doubt, but also a timely one, given the fact that, "ten years after" its completion, the subdued debate is now bound to become "acute" once again. In his one-page testament, Alfred Nobel stipulated that the funds involved should go to outstanding research achievements ("the most important discovery within the domain of physiology or medicine") which during the preceding year had conferred the greatest benefit on mankind. However, the criterion of promptitude explicitly mentioned in the bequest ("during the preceding year") has been dropped. As a rule, the Prize is nowadays given to a contribution made something like a decade before. By this time, the significance of the contribution has become sufficiently clear. Thus, 2010 would be an opportune year for a HGP Nobel Prize to be awarded.

Moreover, as was argued above, the HGP exemplifies the emergence of Big Science in the life sciences, with all the ingredients this involves, ranging from high visibility and lofty societal expectations up to multiple authorship and the intricacies of private-public funding. Thus, the HGP seems to constitute a perfect "test case" for the Nobel Prize as a mechanism of acknowledgment in the era of "big" life science. Still, if the Nobel Prize committee should want to reward the HGP with a Nobel Prize, in view of its scientific and societal significance, how are they to identify the one, two, or three individuals who deserve to be singled out, who may be credited for this achievement?

The first stipulation to consider, no doubt, is whether the HGP has produced significant benefit for humankind. From the very outset, the HGP has been presented as a milestone in the history of both science and humanity. While the project in its early days was often compared to landing on the moon, the societal prospects it opened up were fleshed out in an increasingly detailed manner as the project continued to evolve. As Collins told CNN during a famous interview, it is hard to overstate the importance of reading "our own instruction book." Yet, countless critics have argued that the societal "relevance" of the HGP is far from clear as yet. Although genomics has produced an avalanche of bioinformation, concrete 
social benefits are still sparse compared to the grand promises that have been made at various occasions, such as the claim uttered during the HGP Press Conference (June 26 2000) that "it is now conceivable that our children's children will know the term cancer only as a constellation of stars" (http://www. genome.gov/10001356). Let us, however, for the sake of the argument, give the HGP the benefit of the doubt in this respect, so that we may focus on the key issue of this article: the extent to which scientific achievement in the contemporary biosciences, such as the HGP, can still be meaningfully attributed to individuals, even if, as was already indicated above, Nobel Prizes in Physiology or Medicine are now typically given to three researchers rather than one. I will argue that, for a number of reasons, a "HGP Nobel Prize" (in 2010 or so) would still make sense. But how to select an acceptable and credible set of candidates?

One source of information concerning track record and "practices of the Self" of outstanding scientists are biographies and autobiographies, notably the latter. In recent years, a stream of autobiographical accounts has been published concerning the history of the human genome sequencing effort, such as Collins (2006), Crick (1988), Hood (2002), Sanger (1988), Shreeve (2004), Sulston and Ferry (2002/2003), Venter (2007) and Watson (2000), but the list will no doubt continue to expand. These are, if anything, moral documents, devoted to self-assessment, selfcriticism and self-justification. In virtually all of them, for instance, issues of agency and responsibility are explicitly addressed. To what extent can individuals really be seen as authors of their scientific lives, as autonomous decision-makers? Rather than presenting themselves as heroes of science, in full control of the events, even highly visible scientists such as Sulston, Collins and Venter emphasize (albeit in terms of their own personal vocabularies) how they see themselves as team workers, as products even, rather than as initiators-describing in a lively manner how they, notably at crucial moments, had the experience of being "pulled", "swept" or "driven" by events, the outcomes of which were often impossible to predict from an individual perspective. Their autobiographies describe complex processes of interaction, involving both intricate social dynamics and individual initiatives, and we cannot say that primacy is given to the latter. The grand efforts these authors were officially heading are described in terms of unpredictability, uncontrollability - sheer chaos even - rather than as exemplifications of top-down, management-driven "planning and control." Moreover, after reading the reminiscences of Sulston, Collins and Venter one is bound to realize that, although their role was important, it was limited as well. After reading Venter's autobiography, for instance, in combination with Shreeve's history (2004) of the companies (TIGR and Celera) he headed, it is clear that in various respects, researchers like Gene Myers, Mark Adams or Hamilton Smith were at least as important in terms of decisive scientific contributions as was Venter himself. Thus, eventually, individual contributions must become contextualized again in a more comprehensive view of science as team or network work.

Still, I want to argue that, eventually-notwithstanding the astonishing scale and complexity of contemporary research efforts, notably in the lifesciences - individuals can make a difference at times (notably at crucial moments), and that these decisive contributions are meaningfully attributable as well. When Francis Collins was appointed Director of the HGP in 1993, he already had an impressive track record as a "gene hunter." He had made a name for himself by developing gene-finding methods such as positional cloning and chromosome jumping, and by discovering the location of three important disease genes, namely those responsible for cystic fibrosis, neurofibromatosis and Huntington's disease (Collins et al. 1987). Thus, assessed in terms of more or less traditional criteria, focusing on single individuals as researchers, a nomination for the Nobel Prize would already make sense. Yet, in subsequent stages of his career, he was willing and able to develop complementary skills as well, and to excel in other fields. After successfully taking the lead in the human genome venture, he was recently appointed as director of the National Institutes of Health $(\mathrm{NIH})$, an acknowledgement of his managerial performance. Moreover, he presented series of lectures on the societal aspects of genomics and significantly contributed to debates on this issue through interviews and panel discussions. Thus, besides academic research papers, he also published or co-authored a number of influential papers on the prospects of genomics for society (Collins 1999) - the famous 
"benefits for mankind" to which Alfred Nobel's will refers.

Or take the case of Craig J. Venter. Much earlier than most of his competitors, he acknowledged and understood the importance of automated sequencing and some of the specific methodologies involved in this, such as the EST (Expressed Sequence Tags) technique he invented, in combination with the notorious whole-genome "shotgun" approach. The string of genome publications in the 1990s in which he was highly involved, such as the ones on the EST technique (Adams et al. 1991) and on the Drosophila genome sequence (Adams et al. 2000) made him one of the most highly cited researchers, while the comparatively small teams he marshaled produced staggering amounts of bioinformation. And his publication on the human genome (Venter et al. 2001) was not the end of his career. Rather, he subsequently set sail in order to sequence the metagenome of oceanic life forms. As Kevin Davies (2002) argues, although Venter's restless ambition and single-minded opportunism have alienated him from many of his fellow scientists, his trailblazing accomplishments in DNA sequencing over the past decade justify a Nobel Prize. Besides that, he was a pioneer in other fields as well, developing new approaches in science management through private-public partnerships and valorization. His well-documented experiences in this realm provide ample material for reflection, also on the risks and pitfalls involved in introducing such strategies in science. And finally, like Collins, though lectures, interviews and, eventually, his autobiography, he contributed significantly to current debates on the societal meaning of genomics and the HGP and on the implications it has had for our understanding of ourselves as well as of life on earth. Of course, he did not do all this single-handedly-he had an eye for recruiting talent as well as for acquiring substantial funding. But when it comes to assessing the HGP, the sometimes-decisive interventions and contributions of individuals such as Collins and Venter are impossible to ignore.

If we adopt this line of reasoning, however, the focus is bound to shift from one particular and definite contribution ("discovery") to an extended performance, turning the Nobel Prize into a "lifetime award." The Nobel Prize would then be granted not on the basis of an assessment of a single discovery or publication, but rather on the basis of a track record, a whole career, a curriculum vitae that not only involves laboratory achievements (technoscientific genius), but managerial and communicational talents and achievements as well. The problem then remains whether it is fair and meaningful to single out individuals (rather than, for instance, institutes or teams) in a time of mass production of knowledge claims. Before World War II the Nobel Prize had almost always been awarded to a single individual. In the more recent past, it has become standard practice to select three laureates a year. This already indicates that, as a reward mechanism, the Nobel Prize acknowledges and reflects the increase of scale that has taken place in science. Yet, in my view, to further expand this trend-for instance, by singling out teams, consortia or institutes rather than individuals as possible laureates-would be deplorable as a symptom of anonymisation. As individual effort continues to be a crucial element in the dynamics of science, the acknowledgement of individual achievements remains important as well. As was argued above, the Nobel Prize is one element (a highly prestigious and visible element no doubt) in a complex network of symbolic "mechanisms of acknowledgement." As the complexities of the knowledge production process continue to increase, the mechanisms involved must no doubt become more adaptive, differentiated and sophisticated as well in order to remain meaningful and effective. This does not imply, however, that acknowledgement of individual achievement as such is something of the past. Nobel committees of the future face a difficult and complicated task. Nonetheless, achievements deserve to be acknowledged, and some achievements more than others.

If we agree that the human genome sequence effort still merits an "individual" Nobel Prize, who should be the laureates? As other candidates such as James Watson, John Sulston and Hamilton Smith will have to be dismissed, simply because they have already been awarded the Nobel Prize for Physiology or Medicine (and scientists can become a "Physiology or Medicine" laureate only once in a lifetime), the idea of a Nobel Prize for Collins and Venter-preferably in 2010 - appears a plausible one, on the basis of their measurable and quantifiable performance. A Nobel Prize for Collins and Venter would underline that over and above being excellent researchers earlier in their careers, these individuals became outstanding research managers somewhat later in their lives. And these management responsibilities involved not only 
scientific and managerial skills, but also the ability to address the complex societal issues involved and to effectively deliberate these issues with policy makers, politicians, entrepreneurs, journalists and the public at large. Moreover, to the extent that individuals such as Collins and Venter are acknowledged for their exceptional merits as research managers, their Nobel Prizes will be indirectly awarded to the teams they represent, thereby acknowledging the less visible geniuses whom they recruited to work behind the scenes.

When it comes to awarding the Nobel Prize to Collins and/or Venter, another hazardous issue will be to what extent modes of funding should be taken into consideration. Officially, while Collins headed the publicly funded sequencing effort, Venter led a privately owned company with a stock market quotation. As the history of the Nobel Prize reflects the idea that academic excellence in combination with working for the benefit of society is somehow incompatible with striving for personal financial gain, this would considerably compromise Venter's chances. Yet, also in this respect, it has become increasingly difficult to interpret the world in terms of convenient moral dichotomies. Contemporary funding policies for academic research increasingly rely on the emergence of private-public consortia. Not only the funding strategies, but also the work ethic and the reward systems of universities and knowledge enterprises have begun to merge. Even publicly funded research efforts have become both costly and potentially profitable endeavours. And while Venter at various occasions published staggering amount of genomics data for free, Watson, Collins and most of the other protagonists of publicly funded genomics research privately own patents. Thus, it will become an increasingly intricate matter to determine where to convincingly draw the moral line. Thus, notwithstanding the various complications and considerations at stake, a Nobel Prize for individuals such as Collins and Venter would do justice to the way in which excellent research in the contemporary lifesciences is done. Eric Lander, first author of the official Nature presentation of our genome sequence, would be a convincing "third" candidate to join them.

Open Access This article is distributed under the terms of the Creative Commons Attribution Noncommercial License which permits any noncommercial use, distribution, and reproduction in any medium, provided the original author(s) and source are credited.

\section{References}

Adams, M., et al. 1991. Complementary DNA sequencing: expressed sequence tags and human genome project. Science 252: 1651-1656.

Adams, M., et al. 2000. The genome sequence of Drosophila melanogaster. Science 287: 2185-2195.

Bishop, J.M. 2003. How to win the Nobel Prize. An unexpected life in science. Cambridge: Harvard University.

Collins, F.S. 1999. Medical and societal consequences of the Human Genome Project. The New England Journal of Medicine 341: 28-37.

Collins, F.S. 2006. The language of God: A scientist presents evidence for belief. New York: Free Press.

Collins, F.S., M.L. Drumm, J.L. Cole, W.K. Lockwood, G.F. Van der Woude, and M.C. Iannuzzi. 1987. Construction of a general human chromosome jumping library, with application to cystic fibrosis. Science 235: 1046-1049.

Collins, F., E. Green, A. Guttmacher, and M. Guyer. 2003. A vision for the future of genomics research: a blueprint for the genomics era. Nature 422: 835-847.

Cook-Deegan, R. 1995. The gene wars: Science, politics and the human genome. New York: Norton.

Crick, F. 1988. What mad pursuit: A personal view of scientific discovery. New York: Basic Books.

Davies, K. 2002. Cracking the genome: Inside the race to unlock human DNA. Baltimore: John Hopkins University Press.

Feldman, B. 2000. The Nobel Prize. New York: Arcade.

Foucault, M. 1984. Histoire de la sexualité 2: L'usage des plaisirs. Paris: Gallimard.

Foucault, M. 1994. “Qu'est-ce qu'un auteur.” In Dits et écrits 789-809. Paris: Gallimard.

Friedman, R.M. 2001. The politics of excellence: Behind the Nobel Prize in science. New York: Times Books.

Henig R.M. 2002. http:www.aliciapatterson.org/APF2003/ Henig/Henig.html.

International Human Genome Sequencing Consortium (IHGSC). 2001. Initial sequencing and analysis of the human genome. Nature 405: 860-921.

Hood, L. 2002. My life and adventures integrating biology and technology. A commemorative lecture for the 2002 Kyoto Prize in Advanced Technologies. http://www. systemsbiology.org/download/2002Kyoto.pdf.

de Kruif, P. 1927. The microbe hunters. London: Cape.

Latour, B. 1984/1988. The Pasteurization of France. Trans. A. Sheridan and J. Law. Cambridge: Harvard University Press.

Lenard, P. 1933. Great Men of Science [Große Naturforscher]. London: G. Bell and sons.

Maddox, B. 2002. Rosalind Franklin: The dark lady of DNA. New York: Harper Collins.

Merton, R. 1957/1973. Priorities in scientific discovery. In Sociology of science: empirical investigations, 286-324. Chicago: University of Chicago Press.

Merton, R. 1988. The Matthew effect in science II: cumulative advantage and the symbolism of intellectual property. ISIS 79: 606-623.

Nietzsche, F. 1980. Morgenröte. Sämtliche Werke. Kritische Studienausgabe, Hrsg. G. Colli, M. Montinari. München/ Berlin/New York: DTV/De Gruijter. 
Ostwald, W. 1909. Große Männer. Leipzig: Akademische Gesellschaft.

Pavlov, I.P. 1897/1910. Lectures on the work of the digestive glands. Trans. W.H. Thompson. London: Griffin.

de Solla Price, D.J. 1963. Little science, big science. New York: Columbia University Press.

Sanger, F. 1988. Sequences, sequences and sequences. Annual Review of Biochemistry 57: 1-28.

Shortland, M., and R. Yeo (eds.). 1996. Telling lives in science: Essays on scientific biography. Cambridge: Cambridge University press.

Shreeve, J. 2004. The genome war: How Craig Venter tries to capture the code of life and save the world. New York: Knopf.

Sloterdijk, P. 2010. Scheintod im Denken. Von Philosophie und Wissenschaft als Übung. Frankfurt: Suhrkamp.

Stroop, J.R. 1935. Studies of interference in serial verbal reactions. Journal of Experimental Psychology 18: 643-662.

Sulston, J., and Ferry G. 2002/2003. The common thread: Science, politics, ethics and the human genome. London: Bantam/Corgi.

Todes, D.P. 2002. Pavlov's physiology factory: Experiment, interpretation, laboratory enterprise. Baltimore: John Hopkins University Press.

Venter, C.J., et al. 2001. The sequence of the human genome. Science 291: 1304-1351.
Venter, J.C. 2007. A life decoded. My genome: My life. New York: Viking Penguin.

Watson, J. 2000. A passion for DNA: Genes, genomes and society. Cold Spring Harbor: Cold Spring Harbor Laboratory.

Watson, J., and F. Crick. 1953. A structure for Deoxyribose Nucleic Acid. Nature 171: 737-738.

Wouters, P. 1999. The citation culture (dissertation). Amsterdam: University of Amsterdam.

Zwart, H. 2001. De wetenschapper als auteur. Geschiedenis en toekomst van het wetenschappelijk communiceren (inaugural lecture). Nijmegen: Sun.

Zwart, H. 2004. Environmental pollution and professional responsibility. Ibsen's A public enemy as a seminar on science communication and ethics. Environmental Values 13(3): 349-372.

Zwart, H. 2005. Professional ethics and scholarly communication. In Ethics for Life Scientists, ed. M. Korthals, 67-80. Dordrecht: Springer.

Zwart, H. 2008a. Challenges of macro-ethics: bioethics and the transformation of knowledge production. Journal of Bioethical Inquiry 5: 283-293.

Zwart, H. 2008b. Understanding the human genome project: a biographical approach. New Genetics and Society 27: 353-376. 